\title{
Evaluation of Nitrosyl Ruthenium Complexes Entrapped in an Oil-In- Water Emulsion as Vasodilator Agents
}

\author{
Mario Sergio Pereira Marchesi, Wagner Luiz Heleno Marcus Bertolini, Simone Aparecida Cicillini, \\ Daniella Bonaventura, Lusiane M. Bendhack, Renata Fonseca Vianna Lopez and Roberto Santana \\ da Silva*
}

Faculdade de Ciências Farmacêuticas de Ribeirão Preto - Universidade de São Paulo, Av. do Café s/n. Ribeirão Preto -SP-, 14040-903, Brazil

\begin{abstract}
Several attempts have been made toward the production of oxide (NO)- releasing agents based on metallic complexes. However, many of these agents have been shown to undergo hydroxide electrophilic attack, thus generating the corresponding nitro species. Entrapped nitrosyl ruthenium species can be stabilized in an oil-in-water $(\mathrm{o} / \mathrm{w})$ emulsion and be further used for local NO delivery. This study describes the transdermal permeation of cis and trans$\left[\mathrm{RuCl}(\mathrm{bpy})_{2} \mathrm{NO}\right]\left(\mathrm{PF}_{6}\right)_{2}$ complexes as NO-donor agents from a topically applied emulsion, with NO release rates of 0.042 \pm 0.002 and $0.035 \pm 0.003 \mu \mathrm{mol} / \mathrm{cm}^{2} . h$, respectively. In vitro skin permeation studies performed with the cis and trans$\left[\mathrm{RuCl}(\mathrm{bpy})_{2}(\mathrm{NO})\right]\left(\mathrm{PF}_{6}\right)_{2}$ complexes in $\mathrm{o} / \mathrm{w}$ emulsion showed that they tend to accumulate in the stratum corneum (SC) and viable skin, with spontaneous NO release occurring in the viable skin only. NO release was detected by using an NOsensor when the complexes were in contact with the sonicated skin. The vascular responses to the NO released from the cis and trans- $\left[\mathrm{RuCl}(\mathrm{bpy})_{2}(\mathrm{NO})\right]\left(\mathrm{PF}_{6}\right)_{2}$ complexes in $\mathrm{o} / \mathrm{w}$ emulsion were also evaluated by vasodilation experiments.
\end{abstract}

Keywords: Nitrosyl ruthenium complex, prodrug, transdermal, controlled release, emulsion, targeted drug delivery.

\section{INTRODUCTION}

It is well known that nitric oxide (NO) plays paradoxical roles in the regulation of physiological functions in the body, mediating both normal and injury activities [1-12]. For instance, deficient NO production is involved in the development of vascular diseases, such as hypertension, atherosclerosis and vasospasm [4-6], making exogeneous supplementation of NO necessary. On the other hand, high NO levels have been associated with DNA damage [11, 12]. It seems that controlled local NO delivery is essential to avoid side effects related to the amount of NO. Although several currently available drugs [13] can supply NO to the body, most of them release NO spontaneously. Therefore, it is crucial to develop compounds that provide local NO delivery in a controlled way. Among these agents, the nitrosyl ruthenium compounds have been referred to as a class of substances capable of releasing NO by light irradiation or reduction processes [14]. Such compounds are sometimes unstable at physiological $\mathrm{pH}$, which represents one of the challenges of using them substances in clinical therapy. The topical application of these NO donors, however, enables administration of more acidic formulations. Furthermore, a high local NO concentration could be reached after a specific stimulus.

In this sense, the aim of this study was to evaluate NO release from the NO donor agents, cis and trans$\left[\mathrm{RuCl}(\mathrm{bpy})_{2} \mathrm{NO}\right]\left(\mathrm{PF}_{6}\right)_{2}$, in an oil-in-water $(\mathrm{o} / \mathrm{w})$ emulsion, as well as investigate their passive skin permeation/retention

*Address correspondence to this author at the Faculdade de Ciências Farmacêuticas de Ribeirão Preto, USP. Ribeirão Preto, CEP 14040-903, SPBrazil; Tel: 0055163602 4428; Fax: 0055163602 4253;

E-mail: silva@usp.br and vascular activity in pre-contracted aorta, in vitro. We hypothesize that the topical administration of an NO complex is particularly preferable when the accumulation of foreign materials in the body is concerned.

\section{EXPERIMENTAL PROCEDURES}

\section{Apparatus}

UV-vis spectra were recorded on a Hitachi U-3501 spectrophotometer. IR spectra were recorded on a Protégé 460 series FT-IR spectrometer, using solid samples pressed in $\mathrm{KBr}$ pellets. NO measurements were performed using the Amino-700 NO-meter and Amino-DOS acquisition board. The sensitivity of this apparatus ranged from $1 \mathrm{nmol} / \mathrm{L}$ to 1 $\mathrm{mmol} / \mathrm{L}$, and NO concentration was mesuared by an amperometric technique.

\section{Chemical and Reagents}

The cis and trans-[RuCl(bpy $\left.{ }_{2} \mathrm{NO}\right]\left(\mathrm{PF}_{6}\right)_{2}$ complexes were synthesized by a procedure similar to the one described by Nagao and coworkers [15]. $\mathrm{RuCl}_{3} \cdot \mathrm{nH}_{2} \mathrm{O}$ and 2,2'-bipyridine were purchased as high-purity reagents from Aldrich Chemicals. Liquid paraffin (Chemco), propylene glycol (Synth), emulsifying wax Cetearyl alcohol \& Ceteareth 20 - Paramul $\mathbf{J}^{\circledR}$ (Galena, Brazil) were used as supplied. Double-distilled water was employed in all experiments.

\section{Solubility Studies}

The cis and trans- $\left[\mathrm{RuCl}(\mathrm{bpy})_{2} \mathrm{NO}\right]\left(\mathrm{PF}_{6}\right)_{2}$ complexes ( $25 \mathrm{mg}$ of each) were dissolved in 0.01 mol.L $\mathrm{L}^{-1}$ phosphate buffer solution at $\mathrm{pH} 5.0(5 \mathrm{~mL})$ and maintained under stirring overnight. The solution was filtered using a $0.45 \mu \mathrm{m}$ 
filter membrane (Milipore, USA) and further diluted for UVvisible spectrophotometry measurements.

\section{Skin}

Experiments were performed in full thickness pig ear skins. The tissue was obtained less than $2 \mathrm{~h}$ after animal slaughter (Frigorífico Pontal Ltda, Brazil), and it was used at once or stored in a frezer $\left(-20^{\circ} \mathrm{C}\right)$ for a maximum of 7 days before use.

\section{Preparations of o/w Emulsion}

A simple o/w emulsion consisting of $8 \%(\mathrm{w} / \mathrm{w})$ emulsifying wax (Cetearyl alcohol \& Ceteareth 20), 5\% (w/w) liquid paraffin and $4 \%(\mathrm{w} / \mathrm{w})$ propylene glycol in 0.01 mol. $\mathrm{L}^{-1}$ phosphate buffer solution at $\mathrm{pH} 5.0$ (up to 100) was obtained. Briefly, the oil and the water phase were heated separately to $60.0 \pm 0.1{ }^{\circ} \mathrm{C}$ and mixed together under stirring, until the mixture was cooled to room temperature. cis- $\left[\mathrm{RuCl}(\mathrm{bpy})_{2} \mathrm{NO}\right]\left(\mathrm{PF}_{6}\right)_{2}$ or trans- $\left[\mathrm{RuCl}(\mathrm{bpy})_{2} \mathrm{NO}\right]\left(\mathrm{PF}_{6}\right)_{2}$ complexes were incorporated separately into the prepared emulsions at a concentration of $10^{-3}$ mol. $\mathrm{L}^{-1}$.

\section{In Vitro Release Studies}

The release rates of cis-[RuCl(bpy $\left.)_{2} \mathrm{NO}\right]\left(\mathrm{PF}_{6}\right)_{2}$ or trans$\left[\mathrm{RuCl}(\mathrm{bpy})_{2} \mathrm{NO}\right]\left(\mathrm{PF}_{6}\right)_{2}$ from o/w emulsions at $10^{-3} \mathrm{~mol}^{-1}$ were measured through a $23 \mu \mathrm{m}$ cellulose membrane (MW 12,000 - 14,000, Fisher Scientific Inc., Pittsburgh, PA, USA) in a Franz-type diffusion cell with a diffusional area of $1.2 \mathrm{~cm}^{2} .1 .0 \mathrm{~g}$ of the formulation containing $0.556 \mathrm{mg}$ of the complex (MW: 556) was placed on the membrane surface in the donor compartment, while the receptor contained $4.7 \mathrm{~mL}$ phosphate buffer $\mathrm{pH}$ 5.0. The receptor solution was stirred at $300 \mathrm{rpm}$ and kept at $37.0 \pm 0.1{ }^{\circ} \mathrm{C}$. The latter solution was perfused continuously at $2 \mathrm{~mL} / \mathrm{h}$, to guarantee sink conditions (solubility of the complexes in the receptor was around $3 \mathrm{mg} / \mathrm{mL}$ ), and samples were automatically collected every hour, up to $9 \mathrm{~h}$. At the end of the experiment, the amount of drug that permeated across the membrane was analyzed by UV-visible spectrophotometry at $294 \mathrm{~nm}$. The calibration curve was linear for each complex $(\mathrm{y}=4262 \mathrm{x}+0.450, \mathrm{r}=$ 0.9985 for the cis complex, and $\mathrm{y}=5400 \mathrm{x}+0.517, \mathrm{r}=$ 0.9994 for the trans complex) over the concentration range 2 $\mathrm{x} 10^{-7}$ to $1 \times 10^{-4}$ mol.L $\mathrm{L}^{-1}$.

\section{In Vitro Permeation Studies}

The topical and transdermal delivery of cis and trans$\left[\mathrm{RuCl}(\mathrm{bpy})_{2} \mathrm{NO}\right]\left(\mathrm{PF}_{6}\right)_{2}$ were assessed in vitro using open (not occlusive) modified Franz diffusion cells and porcine ear skin. Briefly, full thickness skin was mounted in a Franztype diffusion cell (diffusional area of $1.2 \mathrm{~cm}^{2}$ ), with the dermal side facing downward into the receptor medium (4.7 $\mathrm{mL}$ of phosphate buffer $\mathrm{pH} 5.0$ ). To achieve higher reproducibility, the skin samples were allowed pre-hydration with receptor fluid for $2 \mathrm{~h}$ before the formulation was applied. The donor compartment was then filled with $1.0 \mathrm{~g}$ of an $\mathrm{o} / \mathrm{w}$ emulsion containing $10^{-3} \mathrm{~mol} . \mathrm{L}^{-1}(0.556 \mathrm{mg} / \mathrm{mL})$ of $\mathrm{cis}$ $\left[\mathrm{RuCl}(\mathrm{bpy})_{2} \mathrm{NO}\right]\left(\mathrm{PF}_{6}\right)_{2}$ or trans-[RuCl(bpy $\left.)_{2} \mathrm{NO}\right]\left(\mathrm{PF}_{6}\right)_{2}$. The system was maintained at $37.0 \pm 0.1{ }^{\circ} \mathrm{C}$, and the receptor medium was stirred at $300 \mathrm{rpm}$ for $12 \mathrm{~h}$. At the end of the experiment, the amount of drug that permeated across the skin was analyzed by UV-visible spectrophotometry at 294 nm.

\section{Skin Uptake}

After the above-described experiment had been allowed to proceed for $12 \mathrm{~h}$, the skin was removed from the diffusion cell and pinned to a piece of Parafilm ${ }^{\circledR}$ with the stratum corneum (SC) facing up ward. Excess non-absorbed formulation/drug was eliminated by thoroughly washing the skin surface with distilled water and carefully wiping it with tissue paper. The skin area that had been exposed to the formulation $\left(1.2 \mathrm{~cm}^{2}\right)$ was tape-stripped 15 times [16, 17] using 3M Scotch Book Tape 845 (3M, St Paul, MN, USA). These tape strips were subsequently immersed in a vial containing $10 \mathrm{~mL}$ acetonitrile for 24 hours, to allow permeant extraction. Extract aliquots were then analyzed by UV-vis spectrophotometry at $294 \mathrm{~nm}$. SC removal was almost complete after 15 successive tape stripping, as indicated by the glistening of the exposed ("viable epidermal") surface [16].

The remaining skin ("viable epidermis") was cut into small pieces, vortex-mixed for $3 \mathrm{~min}$ in $5 \mathrm{~mL}$ acetonitrile, and bath-sonicated for $30 \mathrm{~min}$. An aliquot of the filtered homogenate was then analyzed by UV-visible spectrophotometry at $294 \mathrm{~nm}$. Removed SC or "viable epidermis" containing complexes were also submitted to the extraction procedure and used as blank. Molar concentrations were determined based on a calibration curve.

\section{NO Measurements Using ISO-NO NO-Meter Coupled with Duo-18 Acquisition Board}

NO release from the complexes was measured using a specific NO selective electrode (ISO-NOP NO meter, World Precision Instruments, Sarasota, FL, USA). The calibration curve was prepared by using several dilutions of a known volume of a saturated $\mathrm{NO}$ solution in $10.0 \mathrm{~mL}$ deaerated acetate buffer solution $(\mathrm{pH}=7.4)$. The current value in $\mathrm{nA}$ was recorded for each added volume. NO concentration was calculated according to the reported NO molar fraction solubility $\left(2.1 \times 10^{-3} \mathrm{~mol} . \mathrm{L}^{-1}\right.$ at $\left.25^{\circ} \mathrm{C}\right)$ [14]. The sensitivity of this apparatus ranged from $1 \mathrm{nmol} . \mathrm{L}^{-1}$ to $20 \mu \mathrm{mol} . \mathrm{L}^{-1}$, with a 2-mm sensor, directly detecting NO concentration by an amperometric technique.

\section{Pharmacological Assays}

This study was performed in accordance with the Ethical Animal Committee of The University of São Paulo (Campus of Ribeirão Preto).

\section{Vessel Preparations}

Male Wistar rats $(180-200 \mathrm{~g})$ were killed by decapitation. The thoracic aorta was quickly removed, dissected free and cut into 4-mm-long rings. The endothelium was mechanically removed by gently rolling the lumen of the vessel on a thin wire. The aortic rings were connected between two stainless-steel stirrups, which consisted in an isometric force transducer (F-60 force displacement transducer). A fixed support was introduced into the chamber, in order to record the tension on a polygraph. The rings were placed in a 10.0 $\mathrm{mL}$ organ chamber containing Krebs solution with the following composition (mmol/L): $\mathrm{NaCl} 130, \mathrm{KCl} 4.7, \mathrm{KH}_{2} \mathrm{PO}_{4}$ 1.2, $\mathrm{MgSO}_{4}$ 1.2, $\mathrm{NaHCO}_{3}$ 14.9, Glucose 5.5, $\mathrm{CaCl}_{2}$ 1.6. The solution was maintained at $\mathrm{pH} 7.4$, and it was gassed with $95 \% \mathrm{O}_{2}$ and $5 \% \mathrm{CO}_{2}$, at $37^{\circ} \mathrm{C}$. The rings were initially 
stretched to a basal tension of $1.5 \mathrm{~g}$ before being allowed to equilibrate for 60 minutes in the bath fluid, which was changed every 15-20 minutes. Endothelial integrity was qualitatively assessed by the degree of relaxation caused by acetylcholine (ACh, $\left.1.0 \mu \mathrm{mol} . \mathrm{L}^{-1}\right)$ in the presence of contractile tone induced by phenylephrine $\left(0.1 \mu \mathrm{mol} . \mathrm{L}^{-1}\right)$. Since our studies required endothelium-denuded aortas, the rings were discharged whenever there was any degree of relaxation to $\mathrm{ACh}$, in order to avoid the possible influence of endothelial factors. The tissues were washed and pre-contracted with the $\mathrm{EC}_{50}$ of phenylephrine $\left(0.1 \mu \mathrm{mol} . \mathrm{L}^{-1}\right)$. For the experiments, the chamber was loaded with $0.5 \pm 0.012 \mathrm{~g}$ of the $\mathrm{o} / \mathrm{w}$ formulation containing the NO donor, which was added in a dialysis bag to avoid any adverse physiological effects due to the organic reagents. A similar experiment was run with the control (membrane without the ruthenium complex).

\section{Time-Course for the Relaxation Induced by cis and trans- $\left[\mathrm{RuCl}(\mathrm{bpy})_{2} \mathrm{NO}\right]^{2+}$}

cis or trans-[RuCl(bpy $\left.)_{2} \mathrm{NO}\right]^{2+}\left(1 \mathrm{mmol} . \mathrm{L}^{-1}\right)$ incorporated into the drug delivery system was added to the organ chamber when a stable contraction in response to $0.1 \mu$ mol. $\mathrm{L}^{-1}$ phenylephrine was achieved. The relaxation effect was then analyzed.

\section{RESULTS}

The release profiles of the cis and trans$\left[\mathrm{RuCl}(\mathrm{bpy})_{2} \mathrm{NO}\right]^{2+}$ species entrapped in o/w emulsion were evaluated in vitro (Fig. 1). A linear relationship was obtained for each complex when the amount of released nitrosyl ruthenium was plotted against time, indicating a zero order kinetics. The apparent releasing rates $(\mathrm{k})$, calculated from the slope of that line, are listed in Table $\mathbf{1 .}$

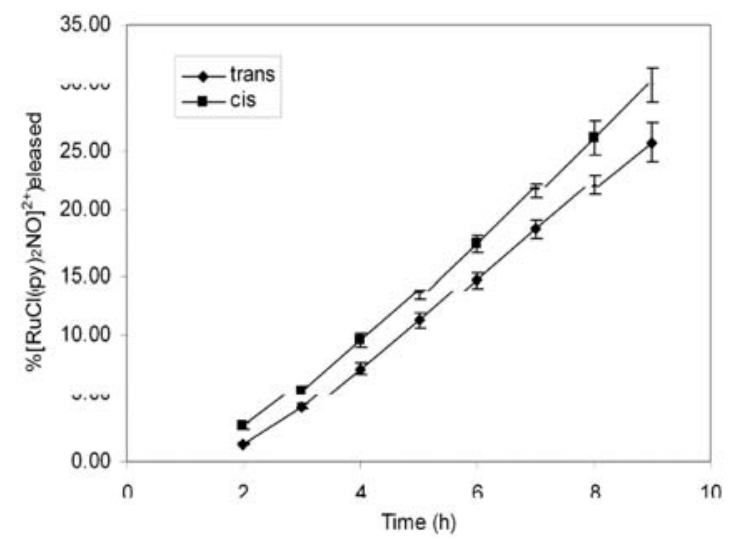

Fig. (1). Nitrosyl ruthenium release profiles from cis$\left[\mathrm{RuCl}(\mathrm{bpy})_{2}(\mathrm{NO})\right]\left(\mathrm{PF}_{6}\right)_{2} \quad$ (square) and trans-[RuCl(bpy $\left.)_{2}(\mathrm{NO})\right]$ $\left(\mathrm{PF}_{6}\right)_{2}$ (circle) complexes entrapped in oil-in-water emulsion.

Table 1. Rate of Nitrosyl Ruthenium Complex Release Entrapped in Oil-in-Water Emulsion (k)

\begin{tabular}{|c|c|c|}
\hline Complex & $\mathbf{k}\left(\mu \mathbf{m o l} / \mathbf{c m}^{2} \cdot \mathbf{h}\right)^{\mathbf{a}}$ & $\begin{array}{c}\text { Linear coefficient } \\
\text { correlation }(\mathbf{r})\end{array}$ \\
\hline \hline cis- $\left[\mathrm{RuCl}(\mathrm{bpy})_{2} \mathrm{NO}\right]^{2+}$ & $0.042( \pm 0.003)$ & 0.993 \\
trans $-\left[\mathrm{RuCl}(\mathrm{bpy})_{2} \mathrm{NO}\right]^{2+}$ & $0.035( \pm 0.002)$ & 0.999 \\
\hline
\end{tabular}

${ }^{\mathrm{a}}$ Means \pm S.D. of the results of three experiments are shown.
The in vitro skin permeation studies revealed that $c i s$ and trans-[RuCl(bpy $\left.)_{2}(\mathrm{NO})\right]\left(\mathrm{PF}_{6}\right)_{2}$ entrapped in $o / w$ emulsion tend to accumulate in the SC (Fig. 2) and viable skin (Fig. 3), with different retention behaviors.

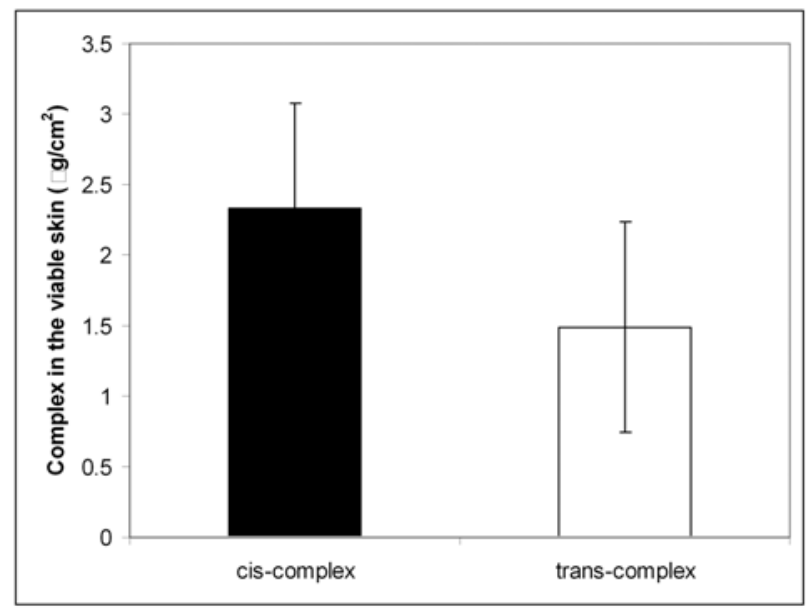

Fig. (2). Retention profile in viable skin of $c i s-\left[\mathrm{RuCl}(\mathrm{bpy})_{2}(\mathrm{NO})\right]^{2+}$ (black) and trans-[RuCl(bpy $\left.)_{2}(\mathrm{NO})\right]^{2+}$ (white).

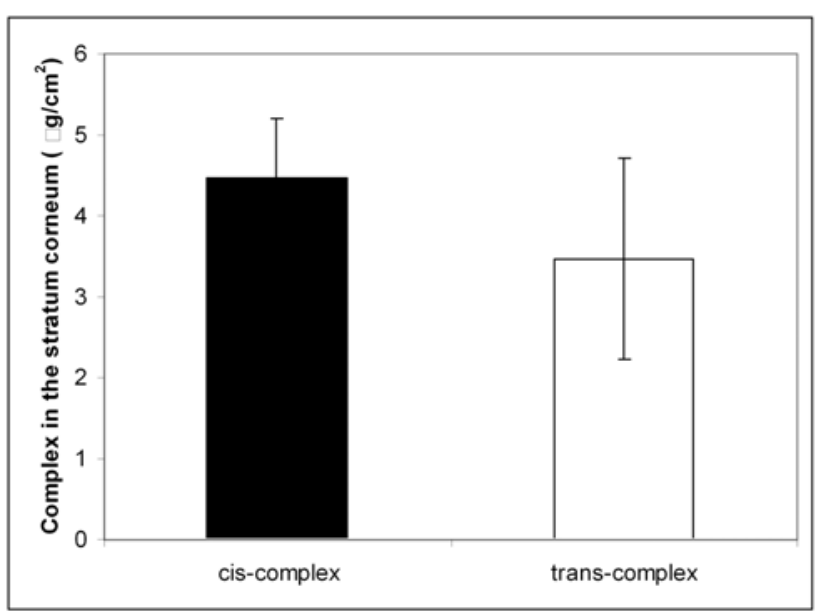

Fig. (3). Retention profile in $\mathrm{SC}$ of $c i s-\left[\mathrm{RuCl}(\mathrm{bpy})_{2}(\mathrm{NO})\right]^{2+}$ (black) and trans $\left[\mathrm{RuCl}(\mathrm{bpy})_{2}(\mathrm{NO})\right]^{2+}$ (white).

The integrity of the molecular structure of cis and trans$\left[\mathrm{RuCl}(\mathrm{bpy})_{2}(\mathrm{NO})\right]^{2+}$ after accumulation in the SC and viable skin was evaluated by UV-visible spectrophotometry. The ruthenium complexes were extracted from the skin with acetonitrile, and the electronic spectrum was compared to those of acetonitrile solutions of cis and trans-[RuCl(bpy) $\left.)_{2}(\mathrm{NO})\right]$ $\left(\mathrm{PF}_{6}\right)_{2}$ (Fig. 4).

The differences in the UV-visible spectra of the extracted and non-entrapped ruthenium complexes suggest that some reaction involving local NO release occurs in the viable skin. To confirm this prediction, intact and sonicated skin pieces were placed in solutions containing cis and trans- complexes. NO release was measured with an NO-sensor, and this phenomenon only when the complexes were in contact with the sonicated skin (Fig. 5).

The effect of NO release from cis and trans$\left[\mathrm{RuCl}(\mathrm{bpy})_{2}(\mathrm{NO})\right]^{2+}$ was investigated from a pharmacologi- 
cal viewpoint by means of vasorelaxation. The denuded aortic rings pre-contracted with phenylephrine responded to the release of $c i s$ and trans-[RuCl(bpy) $\left.)_{2}(\mathrm{NO})\right]^{2+}$ from the $o / w$ emulsion with relaxation. As shown in Fig. (6), vasodilation reached a plateau after $180 \mathrm{~s}$.

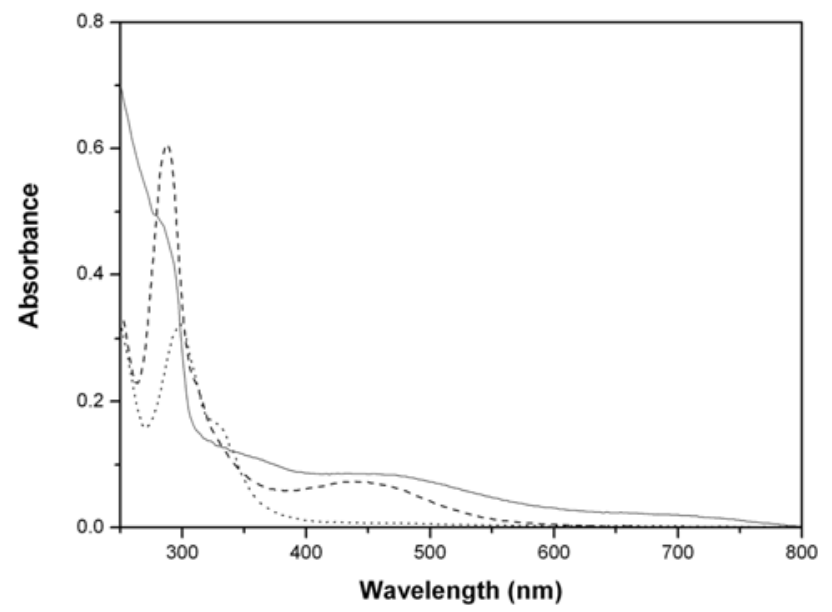

Fig. (4). UV-visible spectrum of the complex extracted from viable skin. cis-[RuCl(bpy $\left.)_{2}\left(\mathrm{H}_{2} \mathrm{O}\right)\right]^{+}$in acetonitrile (dashed line); cis$\left[\mathrm{RuCl}(\mathrm{bpy})_{2} \mathrm{NO}\right]^{2+}$ in acetonitrile (dotted ine) and extracted cis$\left[\mathrm{RuCl}(\mathrm{bpy})_{2} \mathrm{NO}\right]^{2+}$ from SC (solid line).

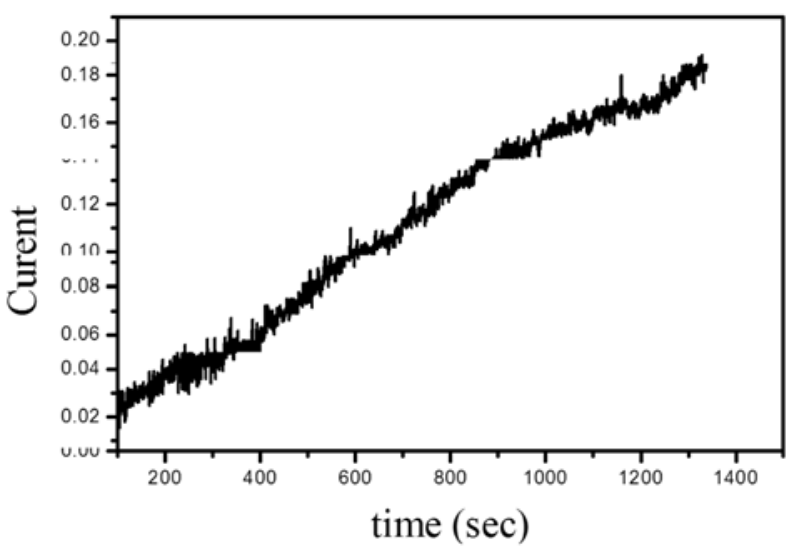

Fig. (5). The NO release profile from $1 \times 10^{-3}$ mol. $\mathrm{L}^{-1}$ of cis$\left[\mathrm{RuCl}(\mathrm{bpy})_{2}(\mathrm{NO})\right]\left(\mathrm{PF}_{6}\right)_{2}$ when in natural skin agent milieu.

\section{DISCUSSION}

The thermodynamic and photochemical properties of cis and trans- $\left[\mathrm{RuCl}(\mathrm{bpy})_{2} \mathrm{NO}\right]\left(\mathrm{PF}_{6}\right)_{2}$ complexes have been previously described [15, 18, 19]. In aqueous solution, both nitrosyl ruthenium species undergo hydrophilic attack in $\mathrm{pH}$ $\geq 5.0$, producing the corresponding nitro species, as described in equation 1 .

$$
\left[\mathrm{RuCl}(\mathrm{bpy})_{2} \mathrm{NO}^{2+}+2 \mathrm{OH}^{-} \longrightarrow\left[\mathrm{RuCl}(\mathrm{bpy})_{2} \mathrm{NO}_{2}\right]+\mathrm{H}_{2} \mathrm{O}\right.
$$

In aqueous solution at $\mathrm{pH} \leq 5.0$, cis and trans$\left[\mathrm{RuCl}(\mathrm{bpy})_{2} \mathrm{NO}\right]^{2+}$ can generate $\mathrm{NO}$ by electrochemical reduction at $-0.20 \mathrm{~V}$ vs. SHE, according to equation 2 .

$$
\left[\mathrm{RuCl}(\text { bpy })_{2} \mathrm{NO}^{2+}+\mathrm{e}^{-} \stackrel{\mathrm{H}_{2} \mathrm{O}}{\longrightarrow}\left[\mathrm{RuCl}(\text { bpy })_{2} \mathrm{H}_{2} \mathrm{O}\right]^{+}+\mathrm{NO}\right.
$$

The NO release profile and the thermodynamic stability of cis and trans-[RuCl(bpy ${ }_{2} \mathrm{NO}^{2+}$ were evaluated in a drug delivery system using an $o / w$ emulsion. Since, despite the similar molecular configurations and chemical properties of these complexes, the corresponding entrapped species could be different and dependent on the molecular configuration and affinity of the ruthenium complexes for the constituent phase (Figs. 1 and 2). cis-[RuCl(bpy) $\left.{ }_{2} \mathrm{NO}\right]^{2+}$ release was slightly faster compared with the complex, probably because trans- $\left[\mathrm{RuCl}(\mathrm{bpy})_{2} \mathrm{NO}\right]^{2+}$ is less water-soluble. So it is possible to hypothesize that trans complex interacts with the emulsion internal oil phase more strongly, thus leading to its slower release.

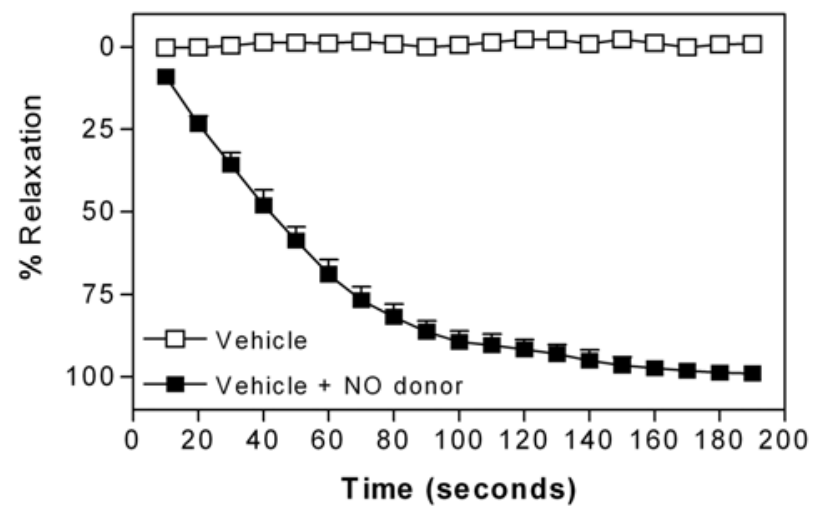

Fig. (6). Time course curve to $c i s-\left[\mathrm{RuCl}(\mathrm{bpy})_{2} \mathrm{NO}\right]^{2+}$ incorporated into $\mathrm{o} / \mathrm{w}$ emulsion (vehicle) in rat aorta pre-contracted with phenylephrine $\left(0.1 \mu\right.$ mol. $\left.\mathrm{L}^{-1}\right)$. Relaxation responses are expressed as $\%$ reversal of the phenylephrine -induced contraction. Data are means \pm S.E.M. of $n$ experiments performed on preparations obtained from different animals.

The in vitro permeation studies also showed that the amount of complexes permeated through the skin was negligible. The trans species tended to accumulate in a lesser amount than the cis species in both the SC and viable skin, probably because of its slightly lower water solubility. However, this difference was not statistically significant.

The stability of the cis and trans-[RuCl(bpy $\left.)_{2}(\mathrm{NO})\right]^{2+}$ complexes in the skin was also evaluated by UV-visible spectrophotometry (Fig. 4). Apparently, the molecular structure of both complexes remained intact in the SC region; the complexes did not undergo any spectroscopic changes as judged by the similarity between the electronic spectra of $c$ is and trans-[RuCl(bpy $\left.)_{2}(\mathrm{NO})\right]\left(\mathrm{PF}_{6}\right)_{2}$ and the corresponding complexes in the SC solution. Nevertheless, both complexes in the viable skin displayed a new band in $460 \mathrm{~nm}$, suggesting their reduction and formation of aquoclorobis(2,2'bipyridine)ruthenium(II) [18]. Therefore, it seems that the viable skin contains sufficient natural reducing agents that allow local NO release, as observed by NO measurement when skin pieces were sonicated in the presence of an NO sensor (Fig. 5). The NO sensor revealed no current variation with non-sonicated skin, even in the presence of cis and trans- $\left[\mathrm{RuCl}(\mathrm{bpy})_{2} \mathrm{NO}\right]^{2+}$. It is possible that ultrasound destroyed the membranes of the epidermis cells, thus releasing cytoplasmatic structures that are able to reduce the nitrosyl ligand in these complexes [16, 17].

The vascular activity of the NO generated from cis and trans-[RuCl(bpy $\left.)_{2} \mathrm{NO}\right]^{2+}$ was also investigated. The entrapped ruthenium complexes maintained the physical 
chemical characteristics observed in aqueous solution [15, 18]. The vasorelaxation mechanism involves reduction of the nitrosyl ruthenium species by phenylephrine, generating NO as described in Equation 2. A similar experiment was carried out with the $o / w$ emulsion containing no nitrosyl ruthenium species, and no vasodilation response was observed (Fig. 6). These results indicate that the $o / w$ emulsion could act as a reservoir of cis and trans-[RuCl(bpy $\left.)_{2} \mathrm{NO}\right]\left(\mathrm{PF}_{6}\right)_{2}$, therefore facilitating the use of these complexes as NO delivery agents in biological assays.

\section{CONCLUSIONS}

The results of the present study show that the local response of the skin to exogenous NO-donor agents at room temperature is not uniform. Interestingly, NO is naturally produced by the reduction of cis and trans$\left[\mathrm{RuCl}(\mathrm{bpy})_{2}(\mathrm{NO})\right]\left(\mathrm{PF}_{6}\right)_{2}$ in the viable skin, and its generation does not depend on external stimulation, although the nitrosyl ruthenium complexes remain unchanged in the SC region. The topical applications used in this study can be considered a non-invasive procedure, and we can therefore conclude that NO release can be controlled by the local amount of nitrosyl ruthenium complexes. NO is site-specifically generated and delivered by transdermal donors, which maybe useful in the treatment of some skin infections. This is enough reason to assume that nitrosyl ruthenium species are potentially applicable in clinical therapy.

\section{ACKNOWLEDGEMENTS}

The authors would like to thank the Brazilian funding agencies $\mathrm{CNPq}$, CNPq-milenium, CAPES and FAPESP for financial support.

\section{REFERENCES}

[1] Ignarro, L.J.; Lippton, H.; Edwards, J.C.; Baricos, W.H.; Hyman, A.L.; Kadowitz, P.J.; Gruetter, C.A. Pharm. Exp. Ther., 1981, 218, 739.
[2] Moncada, S.; Palmer, R.M.; Higgs, E.A. Pharmacol. Rev., 2003, 43, 109.

[3] Bolotina, V.; Najibi, S.; Palacino, J.J.; Pagano, P.J.; Cohen, R.A. Nature, 1994, 368, 850.

[4] Suzuki, M.; Ogawa, A.; Asahara, H.; Endo, S.; Inada K. J. Neurosurg., 1997, 4, 741.

[5] Artigues, C.; Richard, V.; Thuillez, C. Arch. Mal. Coeur. Vaiss., 1998, 8, 1031.

[6] Cannon, R.O. Clin. Chem., 1998, 44, 1809.

[7] Turnbull, C.M.; Rossi, A.G., Megson, I.L. Expert Opin. Ther. Targets, 2006, 10, 911.

[8] Turnbull, C.M.; Cena, C.; Fruttero, R.; Gasco, A.; Rossi, A.G.; Megson, I.L. Br. J. Pharmacol., 2006, 4, 517.

[9] Chvanov, M.; Petersen, O.H.; Tepikin, A. Philos. Trans. R. Soc. Lond.-B, 2005, 360, 2273.

[10] Ignarro, L. Nitric oxide - Biology and Phatobiology, 1st ed., San Diego, 2000.

[11] Ding, X.H.; Hiraku, Y.; Ma, N.; Kato, T.; Saito, K.; Nagahama, M.; Semba, R.; Kuribayashi, K.; Kawanishi, S. Cancer Sci., 2005, 96, 157.

[12] Okazaki, K.; Ishii, Y.; Kitamura, Y.; Maruyama, S.; Umemura, T.; Miyauchi, M.; Yamagishi, M.; Imazawa, T.; Nishikawa, A.; Yoshimura, Y.; Nakazawa, H.; Hirose, M. Cancer Sci., 2006, 97, 175.

[13] Lincoln, J.; Charles, H.V.; Hoyle, G.B. Nitric Oxide in Health and Disease (Biomedical Research Topics), Cambridge University Press, Cambridge, 1997.

[14] a) Ford, P.C.; Lorkovic, I.M. Chem. Rev., 2002, 102, 993. b) Clarke, M.J. Coord. Chem. Rev., 2002, 232, 69. c) Tfouni, E.; Ferreira, K.Q.; Doro, F.G.; da Silva, R.S.; da Rocha, Z.N. Coord. Chem. Rev., 2005, 249, 405.

[15] Nagao, N.; Nishimura, H.; Funato, H.; Ichikawa, Y.; Howell, F.S.; Mukaida, M.; Kakihana, H. Inorg. Chem., 1989, 28, 3955.

[16] Lopez, R.F.V.; Bentley, M.V.L.B.; Delgado-Charro, M.B.; Salamon, D.; Van den Bergh, H.; Lange, N.; Guy, R.H. Photochem. Photobiol., 2003, 77, 304.

[17] de Rosa, F.S.; Tedesco, A.C.; Lopez, R.F.V.; Pierre, M.B.R.; Lange, N.; Marchetti, J.M.; Rotta, J.C.G.; Bentley, M.V.L.B. J. Control Release, 2003, 89, 261.

[18] Togniolo, V.; da Silva, R.S.; Tedesco, A.C. Inorg. Chim. Acta, 2001, 316, 7 .

[19] Sauaia, M.G.; Oliveira, F.D.; Tedesco, A.C.; da Silva, R.S. Inorg. Chim. Acta, 2003, 355, 191.

(C) Marchesi et al.; Licensee Bentham Open.

This is an open access article licensed under the terms of the Creative Commons Attribution Non-Commercial License (http://creativecommons.org/licenses/by-nc/3.0/) which permits unrestricted, non-commercial use, distribution and reproduction in any medium, provided the work is properly cited. 